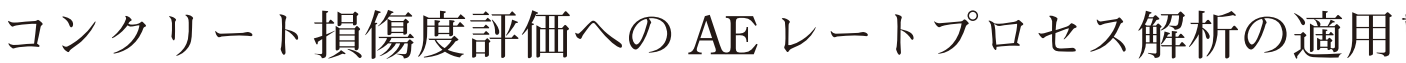

米 野 現 樹* 鈴 木 哲 也*
池 田
幸 史 $^{*}$ 大 津 政 康**

\section{Application of AE Rate Process Analysis to Estimate Damaged Concrete}

by

\author{
Genki Komeno *, Tetsuya SuzukI ${ }^{*}$, Yukifumi IkedA * and Masayasu OHTsu **
}

Damage of concrete is quantitatively estimated by applying AE rate-process analysis and damage mechanics. Controlled-damage specimens are prepared by freezing-thawing and carbonation. $\mathrm{AE}$ behavior in the compression test is analyzed as the rate process. From damage mechanics, a damage parameter is estimated. Using these parameters, compression behavior in concrete is analyzed quantitatively. As a result, it is demonstrated that the degree of damage is estimated quantitatively.

Key words : AE rate-process analysis, Damage mechanics, Freezing-thawing, Carbonation

\section{1 緒言}

コンクリート構造物は，耐久性・経済性に優れたもの として多くの社会基盤に捣いて広く用いられている。近 年, 既設構造物の早期劣化の事例が多く報告されており, 原因としてコンクリートの中性化や凍害などが指摘され ている。このような背景から，コンクリート構造物の損 傷度を定量的に評価するために，構造物の損傷度診断手 法の開発は重要な課題になっている.

筆者らは, $\mathrm{AE}$ 法 ${ }^{1)}$ および損傷力学を応用して, コア供 試体を用いたコンクリート材料の定量的損傷度評価につ いて検討している。これは, コンクリートの圧縮応力下

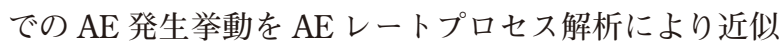
し, 応力一ひずみ挙動から損傷パラメータをローランド モデルにより評価するものである，既に少数のサンプル でも定量的な損傷度評価を行うためのデータベースを構 築し，その有効性も確認している。吕,3),4)

既設構造物では中性化現象や凍結融解現象が多くの劣 化要因としてみられる。そこで本研究では, 実構造物で もっとも確認される劣化現象を実験室レベルで促進処理 により人工的に劣化させた供試体を作成し，圧縮破壊過

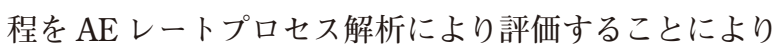
劣化コンクリートの定量的損傷度評価を試みた。

\section{2 解 析 理 論}

\section{$2 \cdot 1$ レートプロセス解析}

コンクリートの一軸圧縮試験下での $\mathrm{AE}$ 発生挙動は, 微小ひび割れの発生過程と対応している。微小ひび割れ は漸増的に発生し, 集積され, 主破壊へと耐力の低下を もたらす。つまり，主破壊に至るまでの過程が微小破壊
の集積とみなされ，既存の破壊域が次の破壊域の進展を 支配すると考えられる。したがって, $\mathrm{AE}$ 発生挙動の定 式化に確率過程論のレートプロセス理論が適用できる.

$\mathrm{AE}$ の発生総数を $N$, 応力レベル $V$ の $\mathrm{AE}$ 発生確率関 数を $f(V)$ とすると, $V$ から $V+d V へ の$ 応力増分に対し レートプロセスとして以下の式を得る。

$$
f(V) d V=\frac{d N}{N}
$$

式 (1)で定義する $\mathrm{AE}$ 発生確率関数 $f(V)$ に対し，損傷 度の定量化のために，次のような双曲線関数を仮定する。

$$
f(V)=\frac{a}{V}+b
$$

ここで, $a, b$ は実験定数である. 式 (1), (2)より応力レ ベル $V$ に対する $\mathrm{AE}$ 発生総数 $N$ の関係は以下の式にのよ うに導かれる。

$$
N=C \cdot V^{a} \exp (b \cdot V)
$$

なお， $C$ は積分定数である. 式 (2)に沶いて示される, 応 カレベルに対する $\mathrm{AE}$ の発生確率関数の例を Fig. 1 に示 す。図より, $a$ 值の正負により $\mathrm{AE}$ 発生確率関数 $f(V)$ は 大きく異なることがわかる， $a$ 值が正の場合, $\mathrm{AE}$ 発生確 率関数 $f(V)$ が低応力で高いことを示し, 劣化していた状 態であると評価することができる。一方， $a$ 值が負なら ば, $\mathrm{AE}$ 発生確率関数 $f(V)$ が低応力で低いことを示し, 健全な状態であると考えられる。

以上のように，レートプロセス解析を適用すれば，一 軸圧縮試験時の $\mathrm{AE}$ 発生挙動を式 (3)で近似することが でき, 得られたパラメータ $a$ 值を用いてコンクリートの 損傷度を定量的に評価することができる.

$\dagger \quad$ 原稿受理 平成 16 年 10 月 28 日 Received Oct. 28,2004

* 熊本大学大学院 干860-8555 熊本市黒髮, Graduate Student, Kumamoto Univ., Kurokami, Kumamoto, 860-8555

** 正会員 熊本大学大学院自然科学研究科 $\overline{7} 860-8555$ 熊本市黒髮, Graduate School of Sci. and Tech., Kumamoto, Univ. Kurokami, Kumamoto, 860-8555 


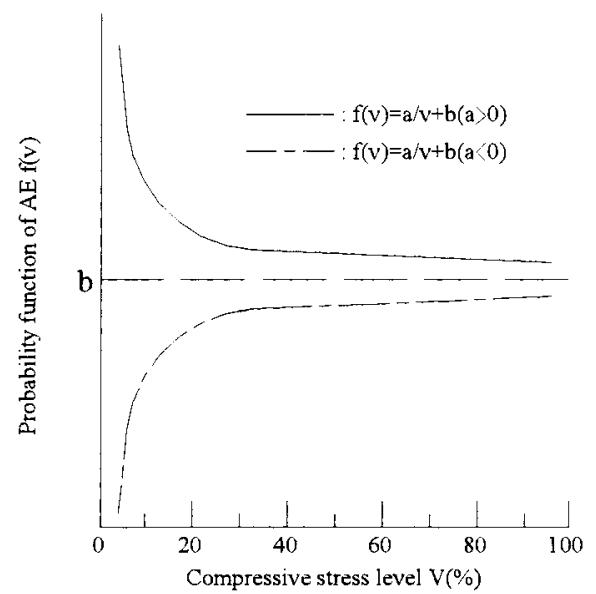

Fig. 1. Two possible relations of probability function $f(V)$.

\section{$2 \cdot 2$ ローランドモデル}

損傷力学に打ける損傷変数 $\Omega$ は弾性係数の相対的変化 として，以下のように定義される。

$$
\Omega=1-\frac{E}{E^{*}}
$$

ここで, $E$ : コンクリートの弾性係数

$E^{*}$ : 無償 (健全な) コンクリートの弾性係数

である。ローランドは，損傷変数 $\Omega$ とひずみ $\varepsilon$ との関係 を以下のように仮定した。

$$
\Omega=\Omega_{0}+A_{0} \varepsilon^{\lambda}
$$

ここで， $\Omega_{0}$ : 一軸圧縮試験開始時点での初期損傷度 $A_{0}, \lambda$ : 材料固有の定数

式 (4), 式 (5)より以下の式が得られる.

$$
\begin{aligned}
\sigma & =E^{*}\left(1-\Omega_{0}-A_{0} \varepsilon^{\lambda}\right) \varepsilon \\
& =E_{0} \varepsilon-E^{*} A_{0} \varepsilon^{\lambda+1}
\end{aligned}
$$

ただし，

$$
E_{0}=E^{*}\left(1-\Omega_{0}\right)
$$

である。

\section{3 実 験 概 要}

\section{$3 \cdot 1$ 供試体}

本実験に使用したコンクリート供試体は, 凍結融解試 験用の角柱供試体 $(100 \times 100 \times 400 \mathrm{~mm})$ を各サイクルに 3 本ずつ計 12 本, 促進中性化試験用の円柱供試体 $(\phi 10 \times$ $20 \mathrm{~mm}$ ) 各サイクル 10 本ずつ計 40 本である。供試体の 作製には角柱供試体では普通ポルトランドセメント（A series), 円柱供試体には普通ポルトランドセメントと高 炉スラグセメント (B series) の 2 種使用した。供試体に 使用したコンクリートの配合条件打よび材料特性は Table I に示す.

\section{$3 \cdot 2$ 水中凍結融解処理 ${ }^{6)}$}

凍結融解処理は JIS A 1148 に則って行った. 28 日水 中養生後に, 供試体の中心温度が $5 \pm 2{ }^{\circ} \mathrm{C}$ から $-18 \pm 3{ }^{\circ} \mathrm{C}$ の範囲を, 3 時間以上 4 時間以内で往復する履歴を与え た供試体を 0，100，200，300 サイクルの 4 段階に分け て作成した。

\section{$3 \cdot 3$ 促進中性化試験}

促進中性化処理はJIS A 1153 に準じて行った。ただし， 圧縮試験が容易なように円柱供試体を用いた。供試体を 28 日水中養生後に上下面をエポキシ樹脂によりコーティ ングし中性化促進装置に入れ，炭酸ガス濃度を $10 \%$ に設 定し，普通セメント，高炉セメントそれぞれ中性化 2 週 齢， 4 週歯令，6 週齢のサンプルを準備した. その後，フェ ノールフタレインを用いて断面方向に中性化深さを測定 した.

\section{$3 \cdot 4$ 一軸圧縮試験}

一軸圧縮試験時の $\mathrm{AE}$ 計測システムを Fig. 2 に示す. なお，供試体上面と下面にはシリコングリースを塗布し， テフロンシートを挿入することにより，載荷摩擦により 発生する $\mathrm{AE}$ の低減に努めた。計測条件として, $\mathrm{AE}$ 計測

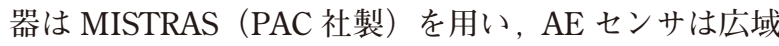
帯型（共振周波数：約 $1 \mathrm{MHz}$ ）のものであり，周波数帯 域は $10 \mathrm{kHz}-300 \mathrm{kHz}, \mathrm{AE}$ センサの出力信号はプリアンプ $40 \mathrm{~dB}$ ，メインアンプ $40 \mathrm{~dB}$ の計 $80 \mathrm{~dB}$ で増幅した。また， $\mathrm{AE}$ の発生数の計測に際して，しきい值は $42 \mathrm{~dB}$ ，不感時

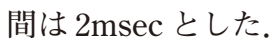

\section{4 実験結果および考察}

\section{$4 \cdot 1$ 力学的特性}

\section{(1) 凍結融解処理}

水中凍結融解試験を行った。供試体はサイクル数の増 加に伴い圧縮強度，弾性係数が低下していることが確認 された。その結果を Table IIに示す。なお， $f_{c}^{\prime} ， E_{0}, E_{c}$ はそれぞれ一軸圧縮強度，初期接線弾性係数，終局割線

\begin{tabular}{|c|c|c|c|c|c|c|c|c|c|c|}
\hline \multirow[b]{2}{*}{ Concrete } & \multirow{2}{*}{$\begin{array}{l}G_{\max } \\
(\mathrm{mm}) \\
\end{array}$} & \multirow{2}{*}{$\begin{array}{l}\text { W/ C } \\
(\%) \\
\end{array}$} & \multirow{2}{*}{$\begin{array}{l}\mathrm{s} / \mathrm{a} \\
(\%) \\
\end{array}$} & \multicolumn{4}{|c|}{ Weight per unit volume $\left(\mathrm{kg} / \mathrm{m}^{3}\right)$} & \multirow{2}{*}{$\begin{array}{c}\text { Air-entrained } \\
\text { admixture } \\
\text { (cc) }\end{array}$} & \multirow{2}{*}{$\begin{array}{l}\text { Slump } \\
(\mathrm{cm}) \\
\end{array}$} & \multirow{2}{*}{$\begin{array}{c}\text { Air content } \\
(\%)\end{array}$} \\
\hline & & & & $\begin{array}{c}\text { Water } \\
W\end{array}$ & $\begin{array}{c}\text { Cement } \\
\text { C }\end{array}$ & $\begin{array}{l}\text { Sand } \\
\mathrm{S}\end{array}$ & $\begin{array}{c}\text { Gravel } \\
\text { G }\end{array}$ & & & \\
\hline & 20 & 55 & 43.1 & 162 & 295 & 749 & 1187 & & 7.9 & 9.3 \\
\hline B series & 20 & 55 & 43.1 & 170 & 310 & 750 & 1005 & 128 & 8.7 & 4.0 \\
\hline
\end{tabular}
弾性係数である.

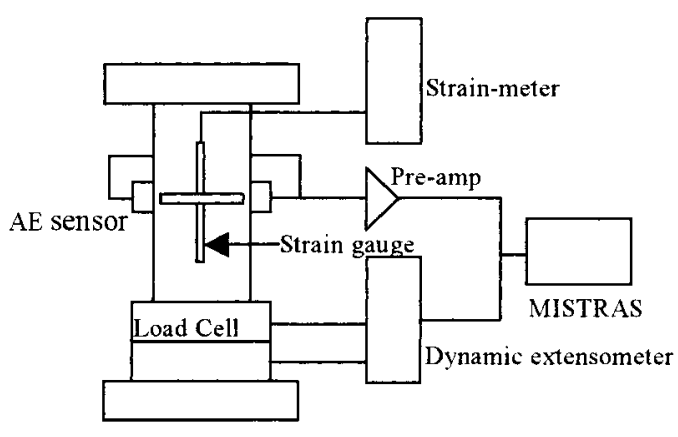

Fig. 2. AE Measuring System.

Table I. Mix proportion and material properties of fresh concrete. 
Table II . Mechanical properties of concrete. (Freezingthawing)

\begin{tabular}{|c|c|c|c|}
\hline & $f^{\prime} c(\mathrm{MPa})$ & $E_{o}(\mathrm{GPa})$ & $E_{c}(\mathrm{GPa})$ \\
\hline 28days & 39.4 & 30.6 & 15.1 \\
\hline 100days & 35.9 & 27.9 & 14.0 \\
\hline 200days & 34.4 & 27.5 & 13.5 \\
\hline 300days & 32.7 & 27.7 & 15.8 \\
\hline
\end{tabular}

\section{（2）促進中性化処理}

促進中性化試験の供試体は週歯令の増加とともに中性化 も進み弾性係数の低下が認められた。なお圧縮強度は, 中性化の進行とともに多少増加する傾向が認められた。 これは，普通ポルトランドセメントおよび高炉セメント を用いた両供試体で確認された。同様の結果は既往の研 究4),5),6)でも示されて打り，中性化に伴うコンクリート 硬化体の空隙構造の変質と圧縮強度が密接に関連してい るものと考えられる。また，供試体の外側から中性化し た位置までの距離を供試体の半径で割ったものを中性化 率として, 普通ポルトランドセメント, 高炉セメントそ れぞれの結果を Table III，Tabl IVに示す.

\section{$4 \cdot 2$ 応力一ひずみ関係}

ローランドモデルによる解析の一例を Fig. 3 に示す. これは普通コンクリートの 28 日養生後の結果である. 図 より解析值と実験值がほぼ一致していることが確認でき る。これより，損傷変数 $\Omega$ を用いたモデルにより，一軸 圧縮下での応力一ひずみ挙動は十分に近似されているこ とがわかる. なおローランドモデルの材料固有の定数 $\lambda$, $A_{0}$ は以下の式 (8), (9) で決定される.

$$
\begin{aligned}
& \lambda=\frac{E_{c}}{E_{0}-E_{c}} \\
& A_{0}=\frac{1}{(\lambda+1) \varepsilon_{c}^{\lambda}}
\end{aligned}
$$

\section{$4 \cdot 3$ レートプロセス解析}

供試体の $\mathrm{AE}$ 発生挙動をレートプロセス理論を用いて 解析した。解析の対象範囲は応力レベルで 30\% 80\% の 範囲とした。これは, 載荷初期に端面で発生する応力レ ベル $30 \%$ 以下での $\mathrm{AE}$ と， $80 \%$ 以上の終局付近で加速度

Table III. Mechanical properties of concrete. (A series, carbonation)

\begin{tabular}{|l|c|c|c|c|}
\hline & $f^{\prime} c(\mathrm{MPa})$ & $E_{0}(\mathrm{GPa})$ & $E_{c}(\mathrm{GPa})$ & Carbonation ratio(\%) \\
\hline 28days & 36.4 & 32.8 & 16.9 & 0 \\
\hline 2weeks & 37.1 & 30.1 & 16.5 & 18 \\
\hline 4weeks & 42.4 & 30.7 & 17.9 & 22 \\
\hline 6weeks & 49.8 & 23.9 & 16.7 & 40 \\
\hline
\end{tabular}

Table IV. Mechanical properties of concrete. (B series, carbonation)

\begin{tabular}{|l|c|c|c|c|}
\hline & $f^{\prime} c(\mathrm{MPa})$ & $E_{0}(\mathrm{GPa})$ & $E_{c}(\mathrm{GPa})$ & Carbonation ratio(\%) \\
\hline 28days & 27.4 & 26.6 & 12.5 & 0 \\
\hline 2weeks & 41.6 & 20.7 & 12.8 & 33 \\
\hline 4weeks & 44.8 & 19.9 & 12.8 & 41 \\
\hline 6weeks & 41.1 & 17.2 & 11.3 & 62 \\
\hline
\end{tabular}

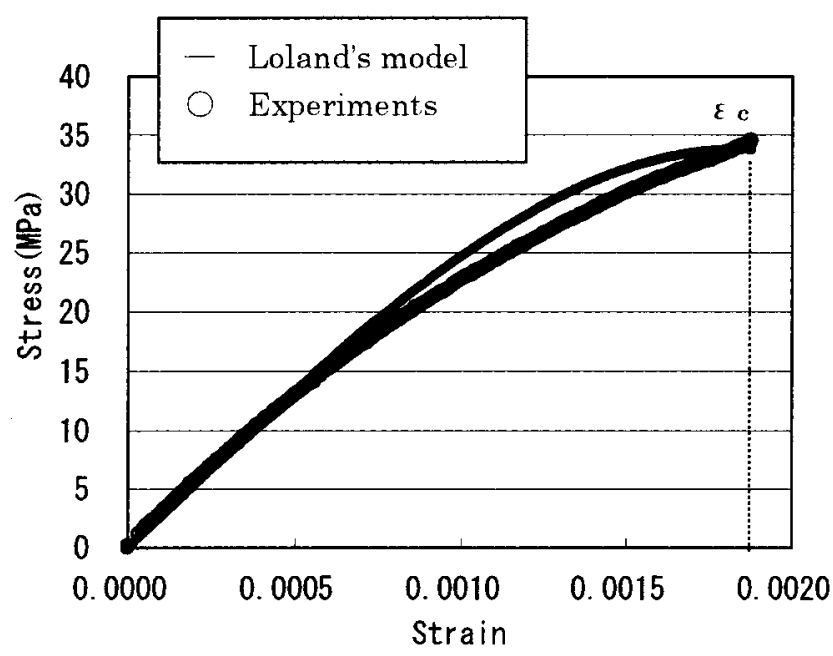

Fig. 3. Stress-strain relation.

的に発生する $\mathrm{AE}$ はコンクリートの損傷度に直接関連す るとは考えられないためである。

凍結融解処理での $\mathrm{AE}$ 発生確率関数と応力レベルの関 係の例を Fig. 4 に示す。 0 サイクルでは応力の増加に対 応して $\mathrm{AE}$ が発生しているのに対し，300サイクルでは 低応力時から $\mathrm{AE}$ が頻発していることが確認できる。こ のとき, $a$ 值はサイクル数の進行に伴い増加することが 確認できる.

同様に, 促進中性化試験についての結果を Fig. 5 に示 す.こちらも 0 週齢のものに比較して 6 週齢たったもの が低応力で $\mathrm{AE}$ が頻発していることが確認できる. 式 (2) により算出される $a$ 值は，A Series，B Series ともに低応

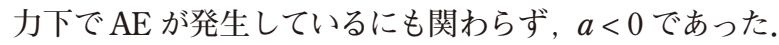
しかし, 凍結融解 0cycle では $a=-0.00123$ なのに対して 300cycle では $a=-0.00039$, 促進中性化試験でも 0 週齢
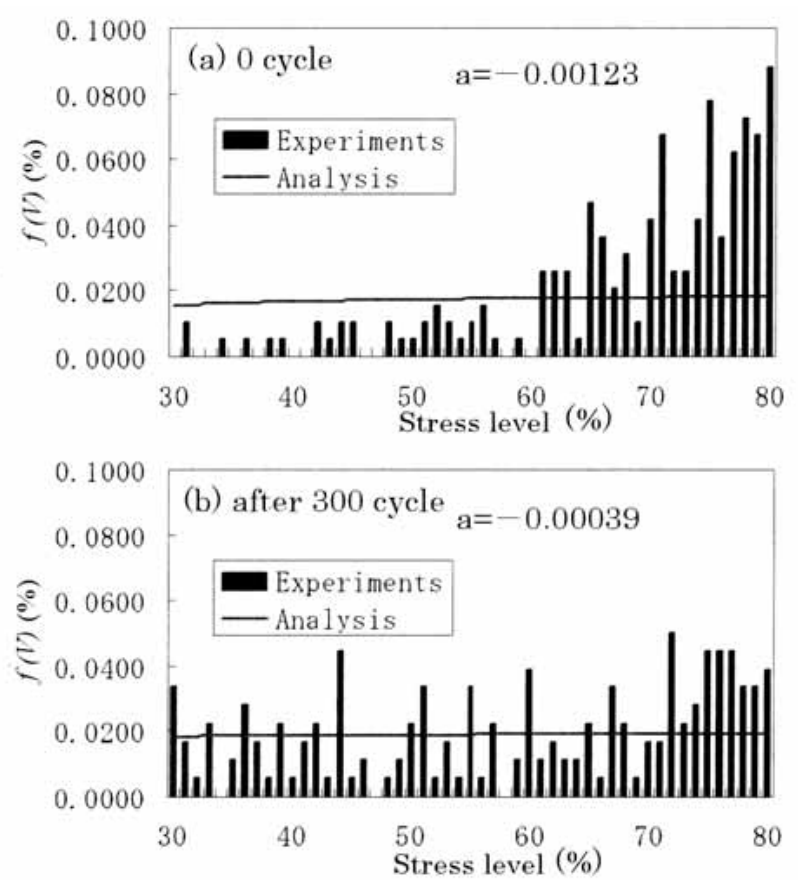

Fig. 4. Relation between $f^{\prime}(V)$ and stress level (freezingthawing). 

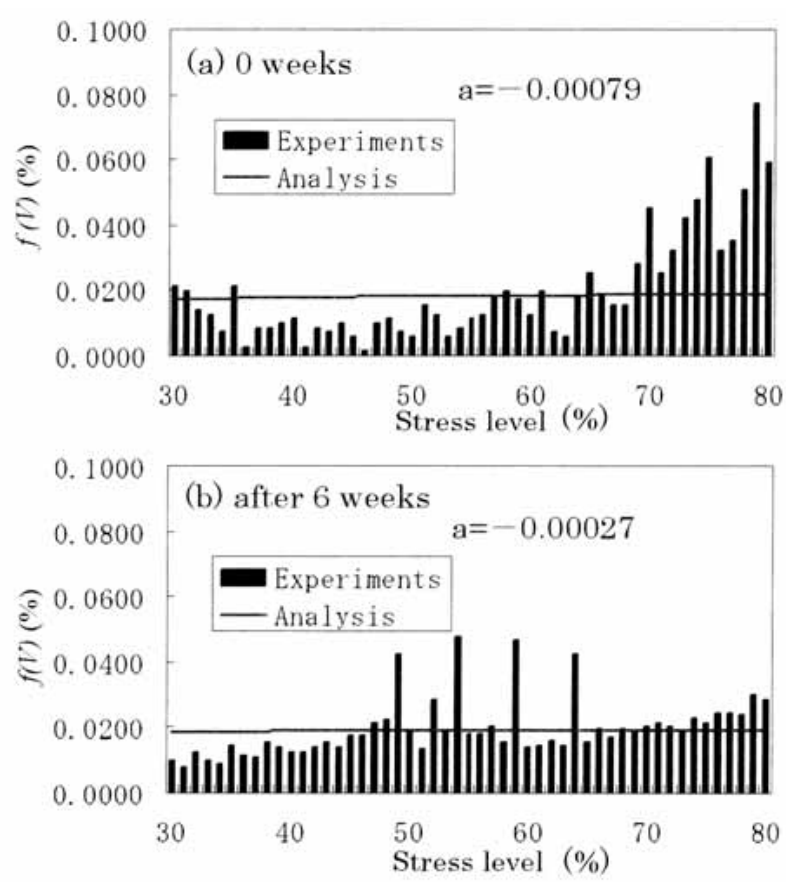

Fig. 5. Relation between $f^{\prime}(V)$ and stress level (B series, carbonation).

で $a=-0.00079$ なのに対して 6 週齢では $a=-0.00027$ と増 加の傾向が確認された。したがって，供試体は，処理進 行に伴い，損傷が蓄積されているものと $a$ 值の結果から 考えられる.

\section{$4 \cdot 4$ 弾性係数の推定による相対損傷度評価}

\section{(1) 健全時弾性係数 $\boldsymbol{E}^{*}$ の推定}

既存の構造物においては，初期物性值が不明な場合が 多く, 調査時点で健全時の弾性係数 $\left(E^{*}\right)$ を得ることは 困難である。そのため，打設時からどの程度劣化してい るのかを確認することができない。そこで，健全時の弾 性係数 $E^{*}$ を $\mathrm{AE}$ 計測結果から推定する手法について考察 をした。

一軸圧縮応力下での弾性係数の低下 $\log \left(E_{0}-E_{c}\right)$ とレー トプロセス解析值 $a$ 值との関係を Fig. 6 に示す.3)

一軸圧縮下での弾性係数の低下 $\log \left(E_{0}-E_{c}\right)$ は式 (4) より,

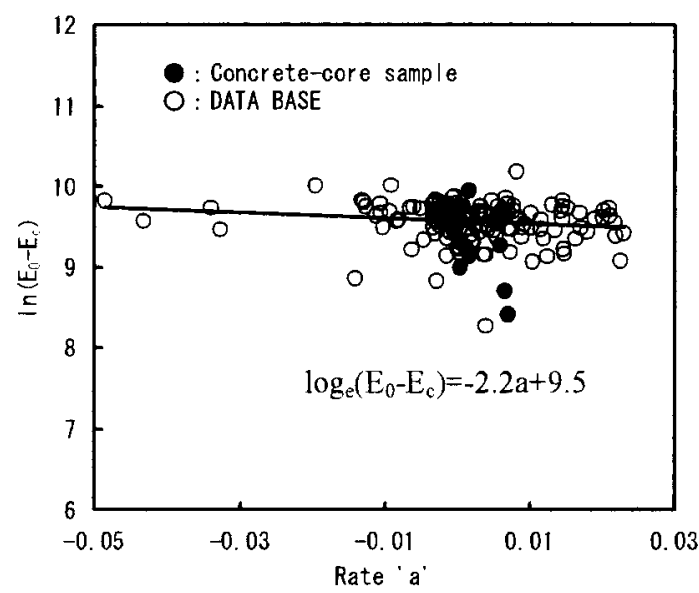

Fig. 6. A Data base of AE arte and elastic modulus.

$$
\begin{aligned}
E_{0}-E_{c} & =E^{*}\left(1-\Omega_{0}\right)-E^{*}\left(1-\Omega_{c}\right) \\
& =E^{*}\left(\Omega_{c}-\Omega_{0}\right)
\end{aligned}
$$

Fig. 6 中の近似式より, 以下の式を得る.

$$
\begin{aligned}
\log _{e}\left(E_{0}-E_{c}\right) & =\log _{e}\left[E^{*}\left(\Omega_{c}-\Omega_{0}\right)\right] \\
& =x \cdot a+y
\end{aligned}
$$

ここで, $E_{0}=E^{*}$ のとき $\Omega_{0}=0, a=0$ と仮定すると， 以下の式 (12)が得られ，健全時の弾性係数 $E^{*}$ の推定が $\mathrm{AE}$ のレートプロセス解析により可能となる.

$$
E^{*}=E_{c}+e^{y}
$$

\section{（2）凍結融解処理した供試体の損傷度評価}

一軸圧縮試験を行った全ての供試体において，実験で 初期接線弾性係数 $E_{0}$ を求め, 実験では凍結融解試験前 の供試体との相対比 $E_{0}{ }^{\mathrm{n}}$ cycle $/ E_{0}{ }^{28}$ と $\mathrm{AE}$ のレートプロセ 又解析により求めた $E_{0}{ }^{\mathrm{n} \text { cycle }} / E^{*}$ を比較した。

凍結融解した供試体は実測值，解析值ともにサイクル の増加とともに低下しこの傾向はほぼ一致していること がわかる (Fig. 7)，これにより，劣化コンクリートにつ いては一軸圧縮試験より求めた $E_{0}$ と式 (10)を用いて算 出した $E^{*}$ とを比較することにより定量的に損傷度を評価 できることが確認できた。

\section{（3）促進中性化処理した供試体の損傷度評価}

Fig. 8 と Fig. 9 に促進中性化処理をした供試体の結果 を示す，週齢の増加とともに実測值，解析值は低下して いる. 相対損傷度 $\left(E_{0} / E^{*}\right)$ の值も 1.0 を下回っており損 傷していることが確認できる。これは中性化の進行に伴い 供試体の材質と空隙構造の変化が低応力時で微小クラッ クを頻発させた結果であると考えられる。また，高炉セ メントを使用した供試体では普通ポルトランドセメント を使ったものと比較して著しく低下していることがわか る。これは既往の研究 ${ }^{9}$ でも示されているように高炉セ メントを使用した供試体の方が中性化の進行が早いため だと考えられる。

\section{5 結 言}

$\mathrm{AE}$ 発生挙動をレートプロセス解析により近似し，応 力一ひずみ挙動をローランドモデルにより評価すること により以下のことが確認できた.

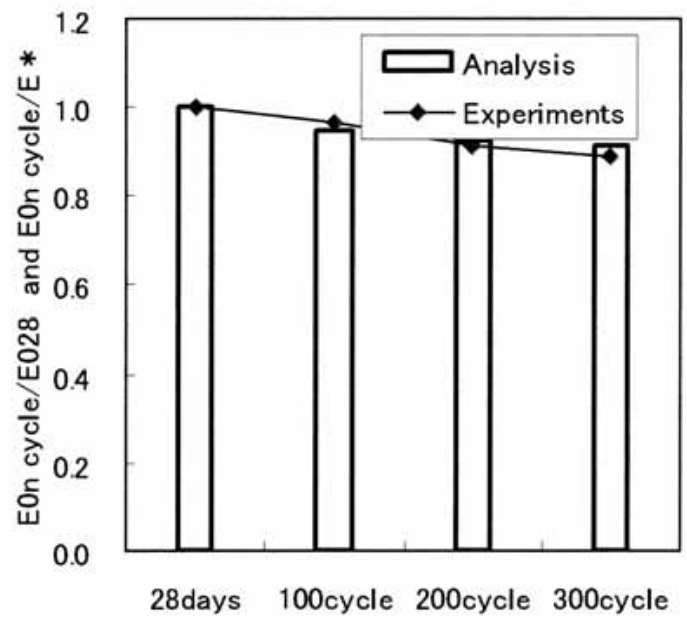

Fig. 7. Relative damage evaluation. (freezinf thawing) 


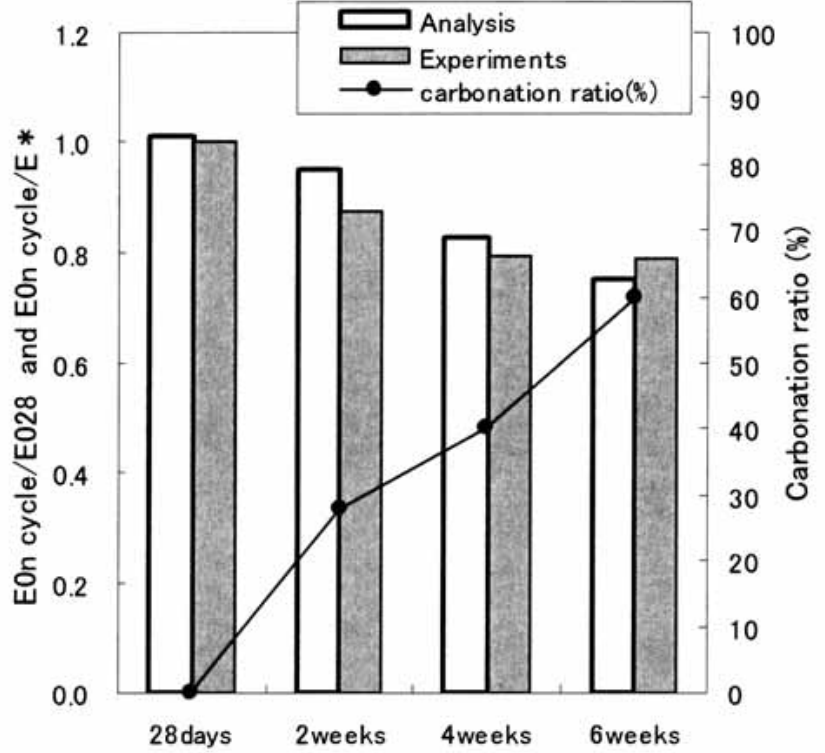

Fig. 8. Relative damage evaluation. (A series)

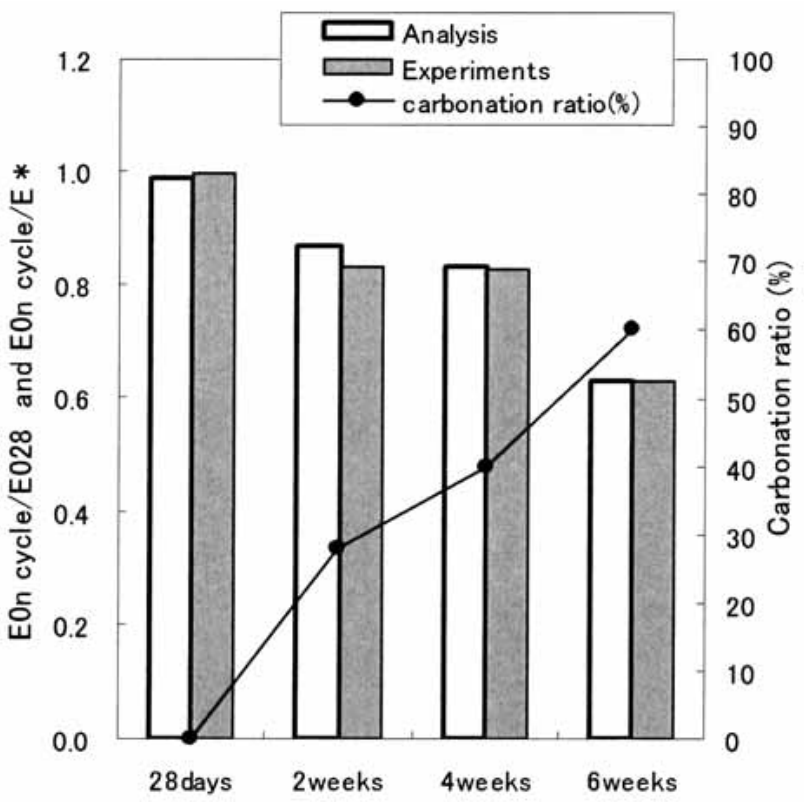

Fig. 9. Relative damage evaluation. (B series)
（1）レートプロセス解析により, $\mathrm{AE}$ 発生挙動は十分 に近似できることが示唆された。

(2) 弾性係数の低下 $\log _{e}\left(E_{0}-E_{c}\right)$ とレートプロセス 解析值 $a$ 值との関係から, 健全時弾性係数 $E^{*}$ を算出し,

一軸圧縮試験で得られる初期接線弾性係数 $E_{0}$ との相対 比を算出することによる相対損傷度評価を行えるの可能 性が示された。

（3）凍結融解処理と中性化処理の供試体を用いること によりにより物理的および化学的損傷を $\mathrm{AE}$ のレートプロ セス解析により定量的に評価できる可能性が示唆された。

\section{参 考 文 献}

1）大津政康, 丹羽義次, “アコースティック・エミッション の特性と理論” p.29（1988）森北出版.

2）鈴木哲也，池田幸史，米野現樹，大津政康，応用力学論 文集， 7，1225(2004).

3 ）鈴木哲也, 池田幸史, 米野現樹, 大津政康, コンクリート 工学年次論文集, 26, 1791 (2004).

4 ）飯田剛史, 渡辺弘史, 友田祐一, 大津政康，コンクリート 工学年次論文集，23，271（2000）.

$5)$ S. P. Shah, S. E. Swarts and C. S. Ouyang, "Fracture Mechanics of Concrete” (1995) John wiley \& Sons Inc. New York.

6 ）(社) 日本材料学会, “新建設材料実験”, p.160 (2000).

7 ）鈴木一孝, 西川直弘, 林 知延, セメント・コンクリート論 文集，43，18(1989).

$8 ）$ 阿部道彦，枡田佳寛，田中 斉，柳啓，和泉意登志， 友沢史紀，日本建築学会構造系論文報告集，409，1 (1990).

9）金 尚奎, 鶴見敬章, 大門正機, セメント・コンクリート 論文集，48，572（1994）。 